\title{
The Damage to the Environment: A View from Law
}

\author{
By Angelina Isabel Valenzuela-Rendón*
}

\begin{abstract}
Environmental damage, being a compelling issue, is the main subject of the present paper studied from a legal perspective. In order to obtain a comprehensive understanding of what environmental damage consists of, a solid definition of environment, its components and limits, should be discussed in detail. The present paper is based on the broadly adopted definition of environment as a system that includes natural resources as well as social and cultural elements. In this context, the concept of damage to the environment is considered to be sui generis in the sense that it is more complex than any other kind of damage. Humans are part of nature, constituting a basic environmental component; therefore, damage may be classified in two categories; indirect damage to the environment and environmental damage direct to people. From this classification the following major issue arises:, if Law does not acknowledge this distinction, damage to the environment may not be properly regulated because of failure to take under consideration the unique characteristics and consequences each type of damage entails. In other words and given that environmental damage is a crucial issue of not solely private but also global interest, in order for Law to properly regulate damage to the environment, this damage classification needs to be accounted for. It is argued that more flexible mechanisms are needed to solve environmental conflicts with the questions expected to arise being the following: Is damage to the environment only a legal concern?, How can a judge quantify the damage?, Who is the competent judge if damage is not static?, Who has the right to file a lawsuit, the people affected or all the interested parties?, What criterium may Law offer to face damage to the environment?, In what cases damage to the environment may be blameworthy? For the purpose of providing a wellgrounded answer to the above questions difficulties in the legal process are analyzed in trials related to environmental damage. Based on the synthesis method, also known as Cartesian or French method, it is observed that only in a few cases the outcome of the trial actually involved a sense of environmental responsibility. Finally, the conclusion reached is that there exists the need of more flexible mechanisms to solve environmental conflicts.
\end{abstract}

Keywords: Environmental damage, Environmental Law.

\section{Introduction}

The two sides of the coin of the environmental issue, namely its protection and damage, have evolved to a pressing matter for the international community. In some countries like Argentina, Bolivia, Brazil, Chile, Colombia, Costa Rica, Cuba, Ecuador, El Salvador, Guatemala, Mexico, Nicaragua, Panama, Paraguay, Peru, Venezuela, Haiti, Honduras, Germany,

${ }^{*}$ Director of the Graduate Studies in Law, UDEM, México. 
Greece, Portugal and Spain, the right to live in a suitable environment has been recognized in their Constitutions.

Unlike these European countries, in the Constitution of the United States of America there is no regulation that expressly recognizes the human right mentioned above. However, as indicated by Ogle, ${ }^{1}$ this may be found in its preamble, which reads:

We the People of the United States, in order to form a more perfect Union, establish Justice, insure domestic Tranquility, provide for the common Defense, promote the general Welfare, and secure the Blessings of Liberty to ourselves and our Posterity, do ordain and establish this Constitution for the United States of America.

Kubasek and Silverman ${ }^{2}$ also determined that this right can be deduced from the IX Amendment of the Constitution of the United States, which establishes that:

The enumeration of the Constitution, of certain rights, shall not be construed to deny or disparage others retained by the people.

Despite the international interest the issues of environmental protection and damage have attracted and due to the multiplicity of environment's elements, there is not a unanimous regulation, determining its components in an explicit manner.

Environmental damage can be classified into indirect-to-humans damage or damage to the environment (strictu sensu environmental damage) and damage directly affecting humans. This distinction allows us to understand that environmental damage exhibits numerous specificities and could be in its core unrelated to the human factor. If Law does not distinguish between the two types of environmental damage, it will therefore be unable to acknowledge the representative traits that differenciate general damage from damage to the environment.

It is important to clarify that our study is conducted from the legal point of view and hence limited to conflicts between private parties, not including international treaties.

Following the Cartesian method, the present paper is divided in two sections. In the first part, the environment's definition and the classification of environmental damage are discussed while environmental damage, its nature and multidimensional impact, is analysed in the second part.

\footnotetext{
${ }^{1}$ Ogle, Ch. 1998. Preamble: relevance to Environmental Law. Does de United States Constitution provide environmental protection? L.A.W. Public interest Law conference. DOI= http://www.conlaw.org/prearg2.htm.

${ }^{2}$ Kubasek, N. and G. Silverman. 1997. Environmental Law. 2nd. ed., Upper Saddle River, Prentice Hall, USA, p. 29.
} 


\section{The Environment and Classification of Environmental Damage}

In order to get a comprehensive understanding of the multidimensionality of environmental damage, a definition of environment and a classification of the damages and risks associated to it should be determined.

\section{The Environment}

Environment is not a synonym of ecology, which is a scientific discipline. The term ecology was introduced by Erns Haeckel in 1866 to describe the discipline that deals with the study of the interaction between the human factor and the environment. ${ }^{1}$

Different criteria are provided concerning the definition of environment with two angles prevailing: the restrictive and the extensive. Martín, ${ }^{2}$ following a restrictive position, considers that the environment is defined exclusively as a system of interactions between living beings. In the context of the extensive standpoint, the environment is considered to be the basis of production and reproduction of cultural goods (such as cultural patrimony) as well as social elements (e.g. social politics), with Lorenzetti even adding the quality of life. $^{3}$

Lezama approaches the definition of environment from the constructivist angle, following Berger and Luckmann's arguments concerning the social construction of reality. According to this line of research, Each society is considered to give a specific meaning to its practices, according to its social order, standards and values. In relation to this process, the interactions between the environment and human behavior are expected to vary across different concepts of social order. ${ }^{4}$

The concept of environment is ductile and, as a consequence, there is no single definition. Currently, the tendency is to expand the definition of environment by including several levels, dimensions and elements of the nature-human factor interactions; for example, Atilio includes natural resources, culture, collective goods or values and historical heritage in the definition of the environment. ${ }^{5}$

Following this trend, the legal viewpoint does not offer uniformity in environmental laws; e.g. the Organic Law of Environment of Costa Rica has only one restricted position ( $2^{\text {nd }}$ Paragraph of the $1^{\text {st }}$ Article). Law 6938/81 of Brazil (Article 3, Section I) and the Canadian Environmental Protection Act of

\footnotetext{
${ }^{1}$ Simental, V. 2010. Derecho ambiental. Limusa, Mexico, p. 34. Brañes, R. 2012. Manual de Derecho Ambiental mexicano. Fondo de Cultura Económica, p. 23. Mosset, J., Hutchinson, T. and Donna, E. 1991. Daño ambiental. Vol. I, Rubinzal-Culzoni Editores, Buenos Aires, p. 15.

${ }^{2}$ Martín, R. 1991. Tratado de Derecho Ambiental. Trivium, Madrid.

${ }^{3}$ Lorenzetti, R. L. 2008. Teoría del Derecho Ambiental. Porrúa, México.

${ }^{4}$ Lezama, J. L. 2008. La construcción social y política del medio ambiente. El Colegio de México, México, p. 25. DOI= http://books.google.com.mx/books?id=J1o_jRh751EC\&print $\mathrm{sec}=$ frontcover $\& \mathrm{hl}=\mathrm{es} \&$ source $=\mathrm{gbs} \_\mathrm{ge} \_$summary_r\&cad $=0 \# \mathrm{v}=$ onepage $\& \mathrm{q} \& \mathrm{f}=\mathrm{false}$.

${ }^{5}$ Atilio, J. 2013. Retos y perspectivas para generar mayor efectividad en el Derecho y la gestión ambiental en los países de Iberoamérica. In Primer Congreso Iberoamericano Derecho y Gestión Ambiental (Lima, Perú, September 25-28, 2014).
} 
1999 (Article 3) maintain an intermediate perspective. The Mexican General Law of Ecological Balance and Protection of the Environment (Section I of the $3^{\text {rd }}$ Article), Mexican Federal Law for Environmental Responsibility, Law 19.300 of the General Basis of the Environment of Chile (Section II, Article 2) and the Environmental Law of El Salvador (Article 5) include a wide concept concerning environment.

According to Bertalanffy, father of the general theory of systems, a system consists of a set of elements in interaction. ${ }^{1}$ The environment, being a global legal good, consists of a system involving natural and social elements that are governed by different manifestations of life. The globality of environment as a legal good lies in the consideration that it is not the legal property of a single individual with its protection being the responsibility of humanity in general.

Humans are one of many components of the environment which brings together biotic and abiotic elements, of the tangible and intangible, concrete and abstract, chemical, physical, biological and social forms. Some examples of biotic elements are plants, microorganisms, animals and humans; abiotic elements are found in air, water, soil and subsoil; monuments, landscapes and urban planning fall into the category of social elements.

\section{Classification of Environmental Damage}

Environment is a system made up of diverse elements, one of which is the human factor, resulting in the fact that lato sensu environmental damage is differentiated in two types on the basis of its connection to the human factor: indirect damage to humans and direct damage to humans. Both types of environmental damage hurt humans as members of a holistic system, with bifurcation not imply that one type can be separated from the other.

Damage to humans is considered to be direct when it affects peoples' patrimony or health. The type of damage that the present paper will analyse is the indirect damage to humans defined as the type which originally causes harm to any element in the environment that is not human. In other words, the present study deals with environmental damage per se. González ${ }^{2}$ refers to this type of damage as pure ecological and De la Puente Brunke ${ }^{3}$ characterizes it as damage by the environment itself. In the context of this study, we will describe it using the term "damage to the environment".

\footnotetext{
${ }^{1}$ Bertalanffy, L. 1989. Teoría general de los sistemas. Fundamentos, desarrollo, aplicaciones. Fondo de Cultura Económica, México, p. 27. DOI= http://archivosociologico.files.wordpress. com/2010/08/teoria-general-de-los-sistemas-ludwig-von-bertalanffy.pdf.

${ }^{2}$ González, J. 2003. La responsabilidad por el daño ambiental en América Latina. In Programa de las Naciones Unidas para el Medio Ambiente (Mexico), p. 26. DOI= http://www.pnuma. org/deramb/pdf/La\%20Responsabilidad\%2012.pdf.

${ }^{3}$ De la Puente, L. 2012. Adecuación del Derecho peruano a las particularidades del daño ambiental: los residuos sólidos peligrosos., Revista Latinoamericana de Derecho y Políticas Ambientales. 2, p. 139. DOI= https://ficheros-2013.s3.amazonaws.com/04/11/Im_1_3_431024 042_in1_21_42.pdf?AWSAccessKeyId=1V02D0W3KSR4KHZ90B82\&Expires=1388300999 $\&$ Signature=aT0DTF1YZZ5jzF1c5uTl3MoHB8E\%3D.
} 
Different authors make distinctions between both types of environmental damage, A quite representative case is Ismael's ${ }^{1}$ who gives a corroboratory example: in the practice of burning a pasture he separates the damage to its sole environmental dimension and the type of damage mostly affecting the people living around the pasture, such as respiratory tract illnesses.

The question that arises in this point is if this distinction is really transcendental. The answer is yes, since it is evident that even though the definition of environment as well as the classification of the types of environmental damage include with different elements, strong interdependence between those elements is the basis of all the relevant phenomena. De la Puente $^{2}$ argues that damage to the environment, independently of the damage to people and property, is singular in nature while involving a level of uncertainty. It is also regarded as a continuous, mutant, disseminative event that can be both permanent and progressive.

The lack of a precise differentiation has resulted in environmental damage not always being regulated in an autonomous manner. Only recently, civil trial attempts have been made to repair the damage that had been generated through time.

González affirms that in the majority of Latin American Legal Systems, environmental damage and damage to elements forming the environment have been treated in the same manner. This had the inappropriate consequence of the application of Civil $\mathrm{Law}^{3}$ in cases of environmental damage, even though the damage to the environment is not a civil damage, and precisely for that reason it should be autonomously regulated.

There has been progress in Mexico regarding this issue, the new Federal Law for Environmental Responsibility now autonomously regulating environmental responsibility, emerging from causing damage to the environment in and of itself ( $3^{\text {rd }}$ Paragraph of the $1^{\text {st }}$ Article).

\section{Damage to the Environment}

This section will clarify the notion and elements of damage to the environment.

\section{The Notion of Damage to the Environment}

Even if the Romans did not specify the concept of damage, they were able to conform to the principle of alterum non laedere (no damage to others). ${ }^{4}$

\footnotetext{
${ }^{1}$ Ismael, J. 2009. De la acción de amparo por responsabilidad ambiental y sus presupuestos de admisibilidad. Equipo Federal del Trabajo, Argentina. DOI= http://www.newsmatic.epol.com.ar/index.php?pub_id=99\&sid=1174\&aid=43407\&eid=49\&NombreSeccion=Notas $\% 2$ 0de\%20c\%E1 tedra\%20universitaria\&Accion=VerArticulo.

${ }^{2}$ De la Puente, L., Op. Cit., p. 139.

${ }^{3}$ González, J., Op. Cit., pp. 27-28.

${ }^{4}$ Barros, E. 2010. Tratado de responsabilidad extracontractual. Jurídica de Chile, Chile, p. 220. DOI= http://ezproxy.udem.edu.mx:2063/source/tratado-responsabilidad-extracontractual5748.
} 
The traditional concept of civil damage is generally defined as damage to property. While it can also include cases of moral damage (Articles 2108 and 1916 of the Mexican Federal Civil Code) it does exclude environmental damage.

Damage to the environment does not represent a loss or harm to property but this does not necessarily mean that a monetary value cannot be placed on it. Environmental damage is something extremely difficult to quantify and appraise since the environment is not an asset exchanged in any type of market thus not having an economic value in and of itself. Hence the question that arises is: how much is the environment worth?

Damage to the environment is not easily quantified for different reasons such as the complexity of determining the specific extent of the damage, its consequences and possible future developments as well as the inexistence of a market value of any of the elements involved. Another property of environmental damage that hinders its quantification is that it could be in progress for a long period of time, rapidly advancing in a way that its full extent cannot be appreciated in the beginning. It is complicated to determine when and where the impact of environmental damage is neutralized, having important implications in procedural questions such as the statute of limitations and jurisdiction according to the judge's territory.

Some of the elements of which environment consists can be cataloged as res communes omnium; they belong to humanity and are not susceptible to appropriation:

\section{"Thing of the (entire) community." (1) The common heritage of all humankind, not subject to the appropriation by or sovereignty (....). ${ }^{l}$}

The concept of environmental damage depends on our sole understanding of the environment. As a consequence, a lack of congruence in that aspect is once again encountered.

In Mexico the Federal Law of Environmental Responsibility defines environmental damage as: 2.- Environmental damage: Loss, change, deterioration, harm, adverse or measurable affectation or modification of the habitat, ecosystems, natural elements or resources, its chemical, physical or biological conditions, relationships of interaction between them, as well as the environmental services provided. Measurable being something that can be measured, ${ }^{2}$ the concept of this law does not avoid the complexity of quantification and appraisal of damage to the environment. However, the concept of environmental damage being the basis of the Federal Law of Environmental Responsibility is evidence that the law system in the right direction of taking under consideration the whole extent of environmental

${ }^{1}$ Fellmeth, A. and Horwitz, M. Guide to Latin in International Law. Oxford University Press, USA. DOI=2011. http://www.oxfordreference.com/view/10.1093/acref/9780195369380.001.0 001/acref-9780195369380-e-1816.

${ }^{2}$ Spanish Royal Academy. 2001. Diccionario de la lengua española. 22nd. Ed., Espasa Calpe, Madrid. DOI=//buscon.rae.es. 
damage in its multidimensionality. The concept of environment is defined in the Mexican Law as habitat; a place with appropriate conditions to support the life of an organism, species or animal or vegetable community. ${ }^{1}$

What happens with future damage to the environment? The national environmental legislation does not specify the repercussions of inevitable future damage. If the damage is certain it will have legal relevance. Urquieta ${ }^{2}$ explains that potential future damage will have legal relevance when it constitutes a prolongation or continuation of the present state of things or if it is unavoidable. Barros $^{3}$ notes that it is more complex to prove future damage than present damage due to the fact that it involves a certain eventuality. Despite the fact that the requirement of certainty of proof is accomplished in the Chilean Law if there is sufficient probability that the damage will be caused, Barros' argument still holds in general.

The following concepts of damage to the environment are found in Comparative Law:

In Chile, in the Law 19.300 on the General Basis of the Environment (Article 2, e) the environmental damage is defined as all significant inferred loss, decrease, detriment or harm to the environment or to one or more of its components.

Article 5 of the General Law of the Environment and Natural Resources of Nicaragua specifies that environmental damage is all loss, decrease, deterioration or harm of the environment or one or more of its components.

Article 27 of Law 25.675 of the General Law of the Environment of Argentina considers environmental damage as all relevant alteration that negatively modifies the environment, its resources, the equilibrium of the systems, or collective goods or values.

In Cuba, Article 8 of Environmental Law Number 81 defines environmental damage as all loss, decrease, deterioration or significant harm, inferred of the environment or to one or more of its components, which are produced by the infringement of a legal norm or regulation.

The concepts of Chilean and Nicaraguan legislations refer to damage produced in the environment and its components without including great details. In Argentina, the Law is more specific and it is interesting to find that it alludes to values, while in Brazil environmental legislation is even more detailed.

In these countries' concepts, no requirement of violation of legal regulation is found, while in Cuba it is clear that it is included as a requirement in the corresponding definition.

In the legislation cited, there is no distinction between damage to the environment and direct environmental damage to people.

In the context of the present study, damage to the environment is considered as the adverse modification of one or more of the elements of the

\footnotetext{
${ }^{1}$ Ídem.

${ }^{2}$ Urquieta, M. 2010. El daño ambiental: los alcances de la voz significativo en su configuración. Universidad Austral de Chile. Chile, p. 19. DOI= http://cybertesis.uach.cl/tesis/ uach/2010/fju.79d/doc/fju.79d.pdf.

${ }^{3}$ Barros, E., Op. Cit., pp. 237-238.
} 
environmental system, or the relationship between them, which does not affect directly humans. The environment should be observed holistically as a system in which damage to any of its elements will have a "domino effect" on its other components or the relationships between them.

\section{Elements of Damage to the Environment}

The elements of damage to the environment are divided in two broad categories: the objective and the subjective.

Objective elements, among which will necessarily exist a causal connection, are the following:

- Cause: environmental impact.

- Effect: adverse modification of environmental elements or of the relationship between them, indirectly affecting humans.

The Federal Law for Environmental Responsibility of Mexico considers that there is no environmental damage when there is no adverse environmental impact (Article 6); this is when there is no violation of legal regulations (general or individual).

In Mexico there can be legal responsibility for the violation of a legal regulation or for the use of dangerous objects.

In the case of the objective elements, their specific identification and description requires a more complicated procedure; for instance, pollution could be often diffuse, slow and imprecise, demanding complicated and costly scientific research to provide solid evidence of its existence. ${ }^{1}$ In addition, the causal link should be also proved; that is the relationship between the incident causing damage to the environment and an adverse modification produced in the environmental system should be specified in detail (Article 36 of the Mexican Federal Law of Responsibility).

The link can often be so indirect that it may be impossible to irrefutably establish it. This uncertainty prevents direct attainment of the repairs demanded, resulting in injustice. ${ }^{2}$

In Chile the responsibility of the perpetrator of environmental damage is legally presumed if there is a violation of the respective regulations. However, indemnity will only be paid if the causal relationship is proven between the infraction and the damage (Article 52 of Law 19.300 on the General Basis of the Environment).

In Argentina, judges could use indirect evidence of precise and concordant presumptions, but this may result in arbitrary judgments.

The presumption of causality is foreseen in the German Law of Unwelthg. ${ }^{4}$

\footnotetext{
${ }^{1}$ Ghersi. 1998. Derecho y reparación de daños. Vol. 3, Universidad, Buenos Aires, p. 57.

${ }^{2}$ Ibídem, pp. 56-57.

${ }^{3}$ Ibídem, p. 57.

${ }^{4}$ Mosset, J., Hutchinson, T. and Donna, E. 1991. Daño ambiental. Vol. I, Rubinzal-Culzoni Editores, Buenos Aires, p. 58.
} 
Patti proposes a reversal of the burden of proof in order for the defendant to be obliged to prove that they have not produced environmental damage. ${ }^{1}$ Atilio also argues that the reversal of the burden of proof is common in the Argentinean Environmental Law. ${ }^{2}$

A more conservative posture consists of only a partial reversal of the evidential burden in which it is obligatory to prove the damage suffered and the behavior of the defendant but not the causal link between these, which can be presumed. $^{3}$

Garzón presents an example of this posture: a factory that releases benzene into the atmosphere, resulting in serious damage to the environment since it pollutes the air with suspended particles, as well as the ground and the water when those particles fall to earth. The defendants prove that the factory uses benzene, that the emissions occur periodically and that the particles in question fall to earth and they stay in the water and in the soil. However, the causal link does not have to be proven. ${ }^{4}$

The subjective elements are the damaging party as well as the damaged party; both can be individual or legal entities. As discussed before, the specification of the subjective elements is not an easy task. How could we prove who causes global warming or who is affected by acid rain?

It is necessary to establish a causal link between environmental damage and the individual/legal entity causing it. If causality is misspecified, it is likely that the damage caused by a person or by their property would be attributed to the wrong person. ${ }^{5}$

Cordobera states that there may be damages of collective nature in the sense that the responsible individual, being a member of a group, cannot be individualized. Collective activities cause damages that can be proven to be even more harmful than the individual ones since power and efficiency as well as dangerousness is in the numbers; additionally, groups can also protect anonymity. ${ }^{6}$

Castañón states that there are systems that have a specific mechanism for channeling responsibility in which there is only one person previously determined as the party responsible for damage; quite representative examples are the nuclear energy contracts of Paris in 1960 and of Vienna in 1963 in which the responsible party is the operator, the Brussels Agreement on Hydrocarbon of 1969 in which the responsible party is the owner of the ship and the Geneva Agreement on the Transportation of Dangerous Merchandise

\footnotetext{
${ }^{1}$ Castañón, M. 2006. Valoración del daño ambiental. In Programa de las Naciones Unidas para el Medio Ambiente (México), p. 41. DOI= http://www.pnuma.org/deramb/documentos/ Valoracion_Dano_Ambiental.pdf.

${ }^{2}$ Atilio, J., Op. Cit.

${ }^{3}$ Garzón, Ú. 2012. Algunas cuestiones sobre las acciones colectivas en materia ambiental. In Revuelta, B. y N. López. Acciones colectivas. Un paso hacia la justicia ambiental. Porrúa, Mexico, pp. 150-151.

${ }^{4}$ Ibídem, p. 151.

${ }^{5}$ Ghersi, Op. Cit., p. 56.

${ }^{6}$ Cordobera, L. 1993. Los daños colectivos y la reparación. Universidad, Buenos Aires, p. 64.
} 
of 1989 in which the person responsible is the transporter (during loading and unloading), the dispatcher of merchandise and the recipient of merchandise. ${ }^{1}$

Damage to the environment can be classified as global and it is possible for it to affect future generations as well.

Barros explains that although the groups affected can be legally determined, there are usually no incentives for them to defend their rights individually or collectively due to the personal and economic costs of filing lawsuits. $^{2}$

The Law has counteracted the problem mentioned. Barros refers to two manners Law has taken:

- In France, a legal individual represents the interests that his associates share as a corporation when intervening legally, such as a professional bar or association.

- As stated by the American Law, in the class or collective actions, procedural media is facilitated so that individuals may exercise an action common to all. ${ }^{3}$

After having proposed a broad definition of damage to the environment and having analyzed its elements, it is concluded that this type of damage has indeed its own characteristics.

In Environmental Law it is difficult to fall back on traditional classifications of damage: patrimonial or extrapatrimonial, certain or uncertain, present or future, personal or someone else's. ${ }^{4}$

Ghersi points out some characteristics of the damage under study hampering its classification as a regular type of damage. It is usually revealed slowly; it can be very large in size and the restoration of things to their previous state is frequently difficult, not economically feasible or even impossible. $^{5}$

In conclusion, some of the main characteristics of environmental harm are: it is generally extra-patrimonial, not always certain, progressive in time and in space frequently slow but with serious effects; it is habitually diffuse; it is difficult or impossible to restore and very difficult to prove.

\section{Results and Conclusions}

There is no unanimous opinion on what the correct core definition of the environment is and, for that reason, what are the elements its damage involves. In Law, there is not always found a distinction between damage to the environment and direct damage to human beings caused by environmental

\footnotetext{
${ }^{1}$ Castañón, M., Op. Cit., p. 39.

${ }^{2}$ Barros, E., Op. Cit., p. 243.

${ }^{3}$ Barros, E., Op. Cit., pp. 243-244.

${ }^{4}$ Mosset, J., Hutchinson, T. and Donna, E, Op. Cit., p. 71.

${ }^{5}$ Ghersi, Op. Cit., p. 38.
} 
harm. It is of great relevance to differentiate between the first and second type of damage since damage to the environment has a sui generis nature.

Damage to the environment is not of the patrimonial type and its quantification as well as the assignment of a specific monetary value to its consequences is complex.

It is not possible for all sorts of environmental damage to cause responsibility, since humankind pollutes simply by existing. Environmental responsibility can be derived from the violation of a legal regulation or from the use of dangerous objects.

There is great difficulty in proving the cause and effect of environmental damage in trials and the relationship between these objective elements. The determination of who the affected party is and who causes the damage is not an easy task either.

The Law must abandon old schemes and respond to current needs emerging from the occurrence of modern environmental problems. More flexible mechanisms are required, granting access to justice for all individuals, in order for repair of damage to be achieved effectively and in due time.

\section{References}

Atilio, J. 2013. Retos y perspectivas para generar mayor efectividad en el Derecho y la gestión ambiental en los países de Iberoamérica. In Primer Congreso Iberoamericano Derecho y Gestión Ambiental (Lima, Perú, September 25-28, 2014).

Barros, E. 2010. Tratado de responsabilidad extracontractual. Jurídica de Chile, Chile. DOI= http://ezproxy.udem.edu.mx:2063/source/tratado-responsabilidadextracontractual-5748.

Bertalanffy, L. 1989. Teoría general de los sistemas. Fundamentos, desarrollo, aplicaciones. Fondo de Cultura Económica, México. DOI= http://archivosociolo gico.files.wordpress.com/2010/08/teoria-general-de-los-sistemas-ludwig-von-ber talanffy.pdf.

Brañes, R. 2012. Manual de Derecho Ambiental mexicano. 2nd. Ed., Fondo de Cultura Económica.

Canadian Environmental Protection Act.

Castañón, M. 2006. Valoración del daño ambiental. In Programa de las Naciones Unidas para el Medio Ambiente (México). DOI= http://www.pnuma.org/deramb/ documentos/Valoracion_Dano_Ambiental.pdf.

Constitution of Argentina.

Constitution of Brazil.

Constitution of Costa Rica.

Constitution of Germany.

Constitution of the Mexican United States.

Constitution of Nicaragua.

Constitution of Peru.

Constitution of Spain.

Constitution of the Portuguese Republic.

Constitution of the Republic of Bolivia.

Constitution of the Republic of Chile. 
Constitution of the Republic of Colombia.

Constitution of the Republic of Cuba.

Constitution of the Republic of Ecuador.

Constitution of the Republic of El Salvador.

Constitution of the Republic of Greece.

Constitution of the Republic of Guatemala.

Constitution of the Republic of Haiti.

Constitution of the Republic of Honduras.

Constitution of the Republic of Panama.

Constitution of the Republic of Paraguay.

Constitution of the Republic of Venezuela.

Constitution of the United States of America.

Cordobera, L. 1993. Los daños colectivos y la reparación. Universidad, Buenos Aires.

De la Puente, L. 2012. Adecuación del Derecho peruano a las particularidades del daño ambiental: los residuos sólidos peligrosos., Revista Latinoamericana de Derecho y Políticas Ambientales. 2. DOI= https://ficheros-2013.s3.amazonaws. com/04/11/Im_1_3_431024042_in1_21_42.pdf?AWSAccessKeyId=1V02D0W3 KSR4KHZ90B82\&Expires=1388300999\&Signature=aT0DTF1YZZ5jzF1c5uTl3 MoHB8E\%3D.

Environmental Law of Cuba.

Environmental Law of El Salvador.

Federal Law for Environmental Responsibility of Mexico.

Fellmeth, A. and M. Horwitz. 2011. Guide to Latin in International Law. Oxford University Press, USA. DOI= http://www.oxfordreference.com/view/10.1093/acr ef/9780195369380.001.0001/acref-9780195369380-e-1816.

García, T. 2007. El principio de la reparación del daño ambiental en el derecho internacional público. Una aproximación a su recepción por parte del derecho mexicano. Anuario mexicano de derecho internacional. VII. DOI= http://biblio. juridicas.unam.mx/estrev/pdf/derint/cont/7/cmt/cmt13.pdf.

Garzón, Ú. 2012. Algunas cuestiones sobre las acciones colectivas en materia ambiental. In Revuelta, B. y N. López. Acciones colectivas. Un paso hacia la justicia ambiental. Porrúa, Mexico.

General Law of Ecological Balance and Protection of the Environment of Mexico.

General Law of the Environment and Natural Resources of Nicaragua.

Ghersi. 1998. Derecho y reparación de daños. Vol. 3, Universidad, Buenos Aires.

González, J. 2003. La responsabilidad por el daño ambiental en América Latina. In Programa de las Naciones Unidas para el Medio Ambiente (Mexico). DOI= http://www.pnuma.org/deramb/pdf/La\%20Responsabilidad\%2012.pdf.

Ismael, J. 2009. De la acción de amparo por responsabilidad ambiental y sus presupuestos de admisibilidad. 49th. Ed., Equipo Federal del Trabajo, Argentina. DOI= http://www.newsmatic.e-pol.com.ar/index.php?pub_id=99\&sid=1174 \&aid $=43407 \&$ eid $=49 \&$ NombreSeccion $=$ Notas $\% 20 \mathrm{de} \% 20 \mathrm{c} \%$ E1 tedra $\% 20$ universitaria $\&$ Accion $=$ VerArticulo.

Kubasek, N. and G. Silverman. 1997. Environmental Law. 2nd. Ed., Upper Saddle River, Prentice Hall, USA.

Law 19.300 on the General Basis of the Environment of Chile.

Law 25.675 of the General Law of the Environment of Argentina.

Law 6938/81 of Brasil.

Lezama, J. L. 2008. La construcción social y política del medio ambiente. El Colegio de México, México. DOI= http://books.google.com.mx/books? id=J1o_jRh751 
EC\&printsec=frontcover\&hl=es\&source=gbs_ge_summary_r\&cad $=0 \# \mathrm{v}=$ onepa ge $\& \mathrm{q} \& \mathrm{f}=$ false.

Lorenzetti, R. L. 2008. Teoría del Derecho Ambiental. Porrúa, México.

Martín, R. 1991. Tratado de Derecho Ambiental. Trivium, Madrid.

Mosset, J., Hutchinson, T. and Donna, E. 1991. Daño ambiental. Vol. I, RubinzalCulzoni Editores, Buenos Aires.

Ogle, Ch. 1998. Preamble: relevance to Environmental Law. Does de United States Constitution provide environmental protection? L.A.W. Public interest Law conference. DOI= http://www.conlaw.org/prearg2.htm.

Organic Law on the Environment of Costa Rica.

Regulation of General Law of Ecological Balance and Protection of the Environment of Mexico.

Simental, V. 2010. Derecho ambiental. Limusa, Mexico.

Spanish Royal Academy. 2001. Diccionario de la lengua española. 22nd. Ed., Espasa Calpe, Madrid. DOI= //buscon.rae.es.

Urquieta, M. 2010. El daño ambiental: los alcances de la voz significativo en su configuración. Universidad Austral de Chile. Chile. DOI= http://cybertesis.uach. cl/tesis/uach/2010/fju.79d/doc/fju.79d.pdf. 
